\title{
LEGITIMATE VIOLENCE IN ILLEGITIMATE TIMES: DIO'S THEORIES OF LEGITIMACY
}

\author{
A L Beek (North-West University)
}

Comparing legitimacy in the three different contexts of literary leisteia, Late Republican civil war actors, and contemporary Severan emperors reveals Dio to be consistent when discussing legitimate violence. In all three, Dio presents establishing legitimacy as a primary factor in attaining power. As the required skills to achieve power differed from those for ruling, the resulting ruler could be disastrous. Through employing the 'noble bandit' topos, Dio questions the emperors' suitability, comparing them to bandits. Overall, Dio interprets Late Republican history differently from his sources for Republican history. In his view, future statesmen cannot rely upon the mos maiorum.

Keywords: Legitimacy, banditry, Cassius Dio, leisteia, mos maiorum.

In the later books of Dio's Roman History, Dio questions the legitimacy of the Roman emperors at several points. While Dio is no opponent of monarchy, he does believe that the system tends to select the wrong figures to be in charge. A further examination of the early fragments of his history suggests he does not believe this to be anomalous; instead, the same mechanics appear in the civil wars of the Late Republic, where legitimacy is a prime consideration. In the early books of his work, Dio answers questions of legitimacy in civil war and returns to these questions again regarding the Severan dynasty. ${ }^{1}$

Moreover, in questioning the legitimacy of the leaders of the state, Dio employs the 'noble bandit' topos, akin to figures seen in Plutarch and Sallust, inter alia. $^{2}$ While others might well take state authority to be ipso facto a legitimate use of power, Dio, I believe, desires to question this assumption: while still putting the Severans in charge and able to defeat bandits and other imperial contenders, he nevertheless questions their suitability by comparing their activities to those of bandits.

1 I would like to thank Carsten Hjort Lange and Andrew Scott for their comments on earlier versions of this piece and their willingness to share numerous works-in-progress with me. I would also like to thank Nicholas Allen for his comments on the present version of this piece. Longer translations of Dio are taken from the Cary Loeb volumes of Dio, translations of shorter passages of Dio and passages from other authors are my own.

2 For this motif of the 'edlen Räubern' in Roman historiography more generally, see Grünewald 1999:94, and 2004:5, 65. 
Dio remains an excellence source for the third century $\mathrm{CE}^{3}$ On the one hand, he was an eyewitness or at least a contemporary observer for the last books of his Roman history. Yet he was not the only observer of his day; there were other sources, such as the writings of Herodian (extant) and the autobiography of Septimius Severus (not extant). Much has been made of his usage of Augustus and comparison of Augustus as a model to the later emperors. His nostalgia for Augustus (and to a degree, Marcus Aurelius) as ideal monarchs is neither new nor unexpected. This discussion, however useful, side-lines the impact of the early books of the history, those covering the civil wars, and it is in these books, I argue, that Dio arrives at his assumptions about what comprises legitimate and illegitimate authority and behaviour, assumptions to which later he returns in his portraits of the emperors, particularly the Severans. ${ }^{4}$

This article steps away from questions of imperial power and senatorial approval (as interesting as they are) to refocus instead upon a question of what precisely is legitimate and illegitimate authority. Dio presents this 'questionably legitimate' authority as effective but nevertheless undesirable. To Dio's eye, what is good and bad has lost ground to what works and what does not. In this way, Dio simultaneously concedes effectiveness to actions he disapproves. And in his view, the Roman glorification of the mos maiorum leads precisely to this problem finding solutions in the mos maiorum are finding solutions of effectiveness, not necessarily solutions of rectitude. Accordingly, Dio implicitly argues that the mos maiorum championed in his historic predecessors (and to a lesser degree, in the Second Sophistic as well) simply does not work. ${ }^{5}$

For better or for worse, Roman study of the mos maiorum generally rested more upon role models than stated principles. ${ }^{6}$ For while a speaker might appeal to

3 For bibliography and discussion on the estimation of Dio as historian, see Scott 2018:1; Lange \& Madsen 2016 passim, esp. the contributions of Schulz and Westall; and numerous contributions in Fromentin et al. 2016:271-414. For the impact of Severus on Dio, see Gleason 2011:37.

4 For the impact of the idealised Augustus and Aurelius as well as the famous debate of Maecenas in book 52, see most recently Scott 2018:6-7; Ando 2016:570-572; Carsana 2016; Coltelloni-Trannoy 2016; Kemezis 2014:126-139. That debate will not be covered in any great detail in this article, but still remains relevant in general terms.

5 While other Greek authors, like Polybius and Plutarch, may have questioned the Romans' faith in the mos maiorum, they generally accepted the Roman principle that the institutions of the Roman past had great merit. For the intellectual traditions of the mos maiorum, see Minyard 1985, with further bibliography. That Dio had been well-educated in the texts of the Latin-language historians is asserted early, at 1.1.2. See also Madsen 2019:468; Scott 2018:15-16.

6 Bell 2008, passim is useful here as an examination of ancient role models more generally. 
ancestral Roman custom in general, the appeal was more effective when that claim was rooted in specific Roman leaders of the past - founder figures whose virtues had been burnished; their flaws somewhat forgotten over the years. These role models (and negative role models) commonly served to illustrate past ideals to look up to and attempt to emulate (as Plutarch explicitly acknowledges). ${ }^{7}$ It was not unusual for Roman authors to disagree about the precise nature of the mos maiorum. ${ }^{8}$ Dio, somewhat unusually for later Roman authors, often presents the wicked in the past, as if to pose in counterargument that in many ways, things have always been this bad. ${ }^{9}$ For moralising precepts, we generally must look more to the set speeches of Dio than the narration of events. ${ }^{10}$ In this way, Dio is markedly unlike a Thucydides, Xenophon, or Polybius, or even a Livy or Tacitus. However, Dio's usage of bandit-episodes (leisteia), both in the early books and the later books, presents a parallel that reveals how Dio thinks about the legitimacy of violence, martial activity, and imperial rule.

\section{Violence, desertion, banditry and illegitimacy}

The Roman state controlled only some aspects of violence. ${ }^{11}$ The paterfamilias had retained extensive rights to inflict violence within the family, masters had power

7 For Plutarch's writing of moral biography, see his statement of purpose at Alex. 1.2, but many examples can be found in the comparisons of his Lives, for example, see his comparison of Alcibiades and Coriolanus (Comp. Vit. Alc. et Cor. 1).

8 See Drogula 2019:65-67 (inter alia) for variations on the mos maiorum, in this case, an examination of Cicero's fight with Cato the Younger over Cato the Elder's understanding of the mos maiorum.

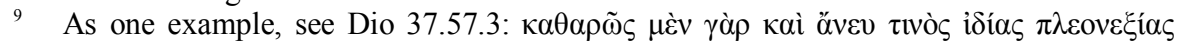

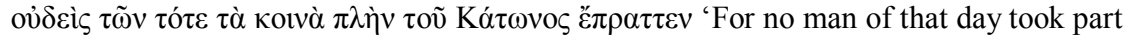
in public life from pure motives and free from any desire of personal gain except Cato' (trans. Cary). See also Libourel 1974 (e.g. 384) for several assessments that Dio is more negative about Republican figures than other Roman historians, and Lange 2019:165166 for the assertion that Dio emphasizes rather than downplays violence during the Republic.

10 See Millar 1964:78-79, esp. '[Dio uses] his speeches not to focus a particular political situation or a particular character, but to set forth the moral sentiments appropriate to the situation'. Here, the 'not to focus on a particular character' is of interest because this was, in other authors, a prime situation to display the merits of the speaker. See also Van Stekelenburg 1976:53.

11 Two particular studies are worth mentioning here: Judy Gaughan's 2010 arguments on much violence being permitted to the average Roman individual show that violence is generally permitted unless specifically prohibited, the reverse of assumptions today. Mabee (2009) shows to a sharp degree that violence was essentially a productive economic category, provided it was done under the correct authorities. On violence in Dio more generally, see also Libourel 1974, who argues that Dio depicts the Republic as 
over the lives of slaves and the state gave significant authority to inflict corporal punishment upon its magistrates. On the other hand, popular riots were grudgingly seen as legitimate, if undesirable, forms of expressing disapproval. ${ }^{12}$ To engage in directed violent activity in public, one required justification, however. And as frustrating as it is to the modern scholar, that justification was less rooted in objective procedure than subjective consensus. Whether the person in question overstepped their authority to engage in violent activity was a matter of public opinion, and as the potency of the riots in Rome show, it was not a public opinion to flout lightly. As one example, Caesar's attempt to triumph over Spain (that is, over Pompey's sons) was not well received. ${ }^{13}$

One of the unspoken provisions of the Late Republic (later spoken as a formal rule) was that generals were not supposed to formally win triumphs from civil war (though they frequently did). The loophole often used, however, was that one could give the war the appearance of being more foreign by triumphing over the non-Roman allies of one's foes. ${ }^{14}$ As Florus quipped: Victores duces externum id magis quam civile bellum videri voluerunt, ut triumpharent. 'The victorious leaders wished it to be seen as a foreign rather than a civil war, so that they might triumph' (Flor. 3.22.9). For obvious reasons, therefore, the state allied to Rome had to assess civil wars cautiously.

Abstention might bring a charge of disloyalty; choosing the wrong side might make one triumph-fodder. Dio shows that clearly in his description of Massilia, which repulsed Caesar during his war with Pompey (41.19), and in his description of the African kings shows Juba grudgingly siding with Pompey and Bocchus and Bogud with Caesar (41.42.7).

stereotypically violent, and Lange 2019 on the topics of internal violence, stasis, and civil war.

12 See Kelly 2007 and to a lesser degree, Kelly 2013, for arguments that the populace was allowed to riot to show disapproval. Kelly argues that while the powers that be might try to restrain it, they did not typically try to retaliate.

13 See Plut. Caes. 56.7-8. It is perhaps worth noting that most other sources do not record this public opprobrium while still holding disapproval themselves (e.g. Suet. Iul. 37-38, 54).

14 Concerning the role of legitimacy and the Roman triumph, see Lange 2016a: esp. 98105. See also Beard 2007:270-272. For the 'formal rule', such as it is, see Val. Max. 2.8.7 and Gell. NA 5.6 As noted by several, e.g. Lange \& Vervaet 2014, Havener 2016, Lange 2016b, many Romans of the late Republic did celebrate their victories over fellow Romans. The point here is that public opinion had to be manipulated to do so. 
Rome's allies might engage in treacherous behaviour themselves. ${ }^{15}$ Rome's typical surety against allied treachery was to take hostages from royal and noble families. As a single example, it may be unclear whether Artoeces, king of Iberia had intended treachery (Dio 37.1-2), but Pompey insisted on hostages before reagreeing to peace. Roman generals might also win over their enemies' allies through bribery. ${ }^{16}$ In Dio's description of Massilia (mentioned above), the Massiliots were the only people in Gaul that did not cooperate, which mildly suggests that the typical Roman ally may have been flexible in these matters.

To an extent, the Roman view on allies was pragmatic distrust - to use them while they stayed loyal. Cicero illuminates one ramification of this Roman realpolitik: the acceptance of continued Cilician banditry by Roman allies as long as they provided good service to Rome. ${ }^{17}$ The earlier Roman Republic saw similar situations with plundering by Numidian auxiliaries, as would the Principate with Gallic and German auxiliaries. Good service to Rome allowed - even required Roman leaders to ignore bandit-like methods by their allies and even the auxilia. In turn, such methods were emphasised by Roman authors as a means of proving the barbarity of these allies. What proved the legitimacy of the allies was not their methods but their loyalty to the state. Interestingly, Dio explicitly makes early and open side-switching more honourable than delayed. ${ }^{18}$ This reveals Dio's marked interest in pragmatic decision-making.

For similar reasons, a frequent demand in peace negotiations was the extradition of deserters to Rome and to Rome's allies. Deserters were well-noted in foreign wars and civil wars alike. ${ }^{19}$ No doubt, Rome's harsh policy towards deserters served as something of a deterrent, even when the deserted-to was a Roman ally. Accordingly, we see key elements of the importance of managing

15 Dio F15 (coming from Zonaras) gives one such example of a bemusing episode of layered treachery. For a later example, see the account of Abgarus, a king who surreptitiously switched sides to Parthia during the expedition of Crassus (Dio 40.20).

16 See Cato in Spain doing so at Dio F60.17 (Zonaras) cf. Dio F100, where Cato's

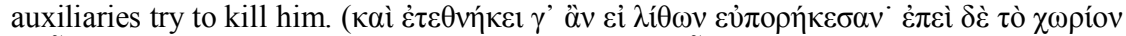

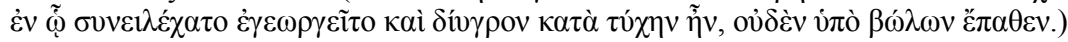

17 Here we might examine the role of Cicero's letters on Antipater of Derbe (Cic. Fam. 13.73-74) alongside Strabo's description (12.1.4). Cicero is also inconsistent on Cilician auxiliaries, who are either his best or worst soldiers depending on his audience.

18 We find this in the case of the comparison of Abgarus and Alchaudonius (40.20-23). Later in his text, we see Dio's surprise at a barbarian ally keeping its promises (The Astingia and Lacringi at 72.11-12).

19 Dio tends to prefer forms of $\delta 1 \alpha \delta i \delta \omega \mu$ for 'to desert', though forms of $\alpha \dot{\tau} \tau o \mu o ́ \lambda o \varsigma$ are common as well for 'deserters'. A few instances in Dio: 19.F20 (Zonaras) has $\delta 1 \alpha \delta i \delta \omega \mu$

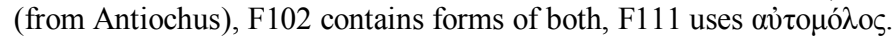


desertion in the following three examples of desertion, all within a roughly fortyyear period:

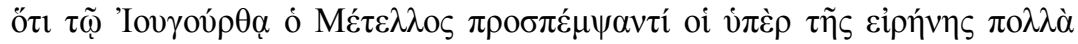

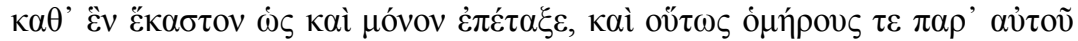

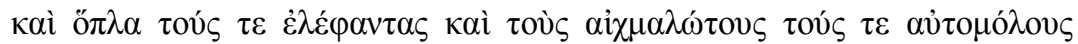

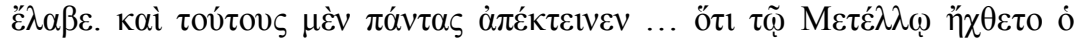

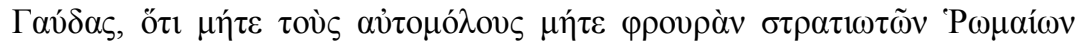

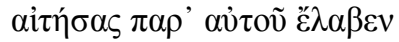

And when Metellus sent to Jugurtha concerning the price of peace, he demanded many things as if each demand were the last one, and this way from him he took in turn hostages, armour, elephants, prisoners and deserters. And Metellus killed all of these (i.e. the deserters) ... and [the Numidian prince] Gaudas was angry with Metellus because despite his requests, Gaudas received neither the deserters nor a bodyguard of Roman soldiers from Metellus ... (Dio 26.F89.1, 89.4, trans. mine).

While in the Numidian example it is not entirely clear who the automoloi are, context suggests that they were ex-Roman soldiers in the employ of Jugurtha, whom Gaudas sought to re-employ as well, as a surety against assassination. The phenomenon of Roman soldiers seeking employment outside of Rome in search of a larger paycheck is not particularly unusual, though we cannot always assume a purely mercenary motive. It was reasonably common for Rome to provide bodyguards to allied kings, though to what degree these were honorary or functional may remain unclear.

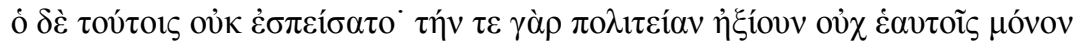

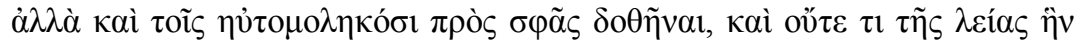

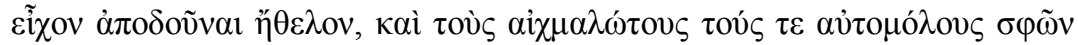

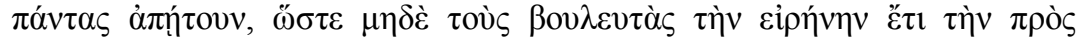

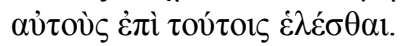

And he [Metellus] did not make peace with them, for they [the Samnites] demanded citizenship to be granted both for themselves and also for those who had deserted to them, they would not return the booty they had taken, and they demanded the return of their captives and those who had deserted from them. After this, the senators no longer desired to obtain peace with them on these terms (Dio F102.7, trans. mine). 
This second example, coming at the tail end of a civil war, accentuates the importance of deserters. ${ }^{20}$ The Samnites insisted on victory-terms vis-à-vis the Romans. Now the quarrel about Roman deserters to the Samnites (who already had Roman citizenship) and the Samnite deserters to the Romans (who would presumably gain citizenship in either case) may have less to do with citizenship than legitimacy. Of course, politeia here may indicate not only citizenship but also the free exercise of citizenship. The crux of the matter is not whether these men will vote, but whether these men will be punished (and unjustified desertion was generally punished by death, which rather makes their voting privileges irrelevant). ${ }^{21}$

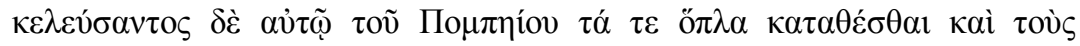

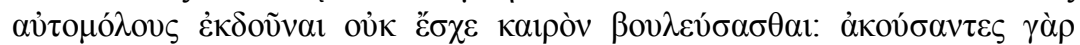

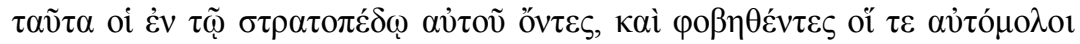

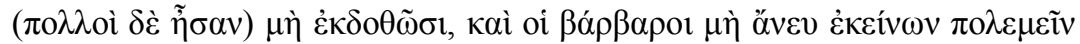

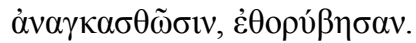

And when Pompey ordered him [Mithridates] to set down his arms and hand over his deserters, Mithridates had no opportunity to consider, for those in his army heard, and the deserters (and there were many), afraid they would be turned over, and the barbarians, afraid they would be forced to fight without them, all made a ruckus (Dio 36.45.4, trans. mine).

The third example is rightly framed as foreign war, but it need not be entirely so. That is, many of the deserters in the army of Mithridates were not recent defectors, but supporters of Marius and Sertorius or proscribed anti-Sullans and their descendants. It is telling that Pompey's offer seemed so limited - that the extradition of the deserters to Mithridates is not merely a pro forma concession but quite a major one. ${ }^{22}$ It is not hard to see a pattern in Roman demands for the return of deserters. The return of deserters is a clear sign of victory and Rome is rarely willing to agree to a peace without this provision. ${ }^{23}$ This was, for example, after the

20 On civil war in Dio, see Lange 2016b, 2019, inter alia, Madsen 2019.

21 Appian (Civil wars 1.49, 1.53) only indicates that the Romans gave citizenship to the allies who did not revolt in the war first and the Samnites and Lucanians last. See also Southern 1996:148-149 on desertion. Southern mentions later examples of desertion in Dio (e.g. 68.9.5; 73.2.2) but not these early ones.

22 It also remains plausible that like the negotiations at Carthage in the Punic Wars (See Dio F57-59 or Zonaras 14 cf. Livy 30 passim) and the negotiations between Metellus and Jugurtha mentioned above, this was not Pompey's final list of demands.

23. A study of Livy and Polybius will reveal that the extradition of deserters is a standard demand of peace terms such as in the second Macedonian war (Polyb. 18.44) or the War with Antiochus (Livy 32.33, Polyb. 18.1-2). 
defeat of Antonius 'Creticus' in 71, the sticking point for a new treaty with the Cretans, who were only willing to return their captives. ${ }^{24}$

Roman leaders might also be less than trustworthy towards their allies. In fighting Perseus, Licinius Crassus sacked several of the cities he was ostensibly there to liberate..$^{25}$ Caesar too is depicted as engaging in semi-treacherous attacks on allies. ${ }^{26}$ These were not unusual in Roman history, they were part of the system of empire. Complicating the matter further is the aforementioned observation that civil war victors in the republic sought triumphs over the allies of the defeated parties, who were arguably simply fulfilling their treaty obligations to Rome, such as was the case for Juba of Africa. Yet some allies unquestionably came down on the wrong side and managed to stay in the good graces of Rome, though perhaps not without intervention. While Caesar initially pardoned the eastern allies of Pompey (Dio 41.62-63), Cicero later had to give a speech (pro rege Deiotaro) on behalf of Deiotarus of Galatia, and the unfortunate Tarcondimotus of Cilicia managed to side with Pompey, the 'Liberators', and Antony each in turn, without resulting penalties from Rome. Some allied kings were portrayed as having tried to become independent from Rome or to gain territory. ${ }^{27}$

Dio's views on this Late Republican self-aggrandizement and these questionable justifications rest in how he thinks about legitimate authority. Banditry was defined principally by the legitimacy of their commander's claim to authority. In this sense, when writers speak against banditry, the rhetorical objection is not to the pillage - common to bandit gangs and state-run armies alike — but instead to the lack of state authority for (and the state's ability to negotiate with) the bandit leader. ${ }^{28}$ In addition, that state authority was crucial to whether the commanders are legitimately employing violence to their ends.

Thus, the leisteia in Dio's work are worth examining as literary loci that may reflect Dio's attitudes towards civil war. ${ }^{29}$ To Dio, uncontrolled soldiers are

24 Dio F111.1.

25 Dio F65.

26 See Dio 37.53, which rather recounts Caesar as too eager to seek out conflicts to win. Similarly, see the account of Claudius and the Salassi (22.74).

27 Judging from Cicero's counterarguments in pro rege Deiotaro, this seems to have been one of the charges. Juba agreed to join Pompey's partisans in exchange for Roman North Africa (Dio 43.4). Pharnaces, one of the only eastern allies not to join Pompey, had offered to join in exchange for Syrian territory (41.55.3), and Caesar later remonstrated with him (41.63.4).

28 This is one of the primary arguments of Beek 2015 and Beek 2019.

29 As noted in de Souza 1999:9-11, Dio prefers katapontistes as a term for the sea-based pirate, though forms of leistes certainly occur. For Dio on Cilician piracy, Gabrielsen 2007:398-401 may be worth examining. 
essentially bandits. ${ }^{30}$ Moreover, indeed we see in book 36 (17-37) an in-depth study of the piracy crisis of the $60 \mathrm{~s}$ BCE, and the resulting grant of an extraordinary command to Pompey. It is not the clearest representation of Dio's attitudes towards monarchy, democracy, and political dynasteia, which might even reflect some degree of ambivalence or uncertainty on Dio's part, but Dio does appear to consider some of Pompey's opponents as modelling later practice. ${ }^{31}$ In particular, Dio simultaneously praises Pompey's (eventual) relinquishment of his powers and army and advises that despite being in accordance with the mos maiorum, it was instrumental in his later defeat by Caesar. ${ }^{32}$ The act is at the same time, both ethical and foolish. Dio also notes Caesar as able but unwilling to hunt bandits (37.52), as this would interfere with his greater political goals, thus reversing the analysis of power-seeking.

\section{Dio's political philosophy}

Like most ancient historians, Dio provides programmatic statements (though the fragmentary nature of the contents poses some uncertainty to the ordering) at the beginning of his first book, where he asserts his purpose. Dio's bald assertion to have read everything he could stands out. His declaration to provide a Romecentred narrative of peace and of war is noteworthy, if not exceptional; other historians often focused on wars (explicitly so in the narratives of Appian or Florus), and Dio's own excerpters provide a greater quantity of fragments concerning war than peace.

While Millar asserted Dio to have little to no theory of history, the same cannot be said of his position on politics and philosophy, or weighing in on the always popular monarchy-aristocracy-democracy debate. ${ }^{33}$ Here, his position might be best summed up as advocating for a variant of monarchy we might call 'restrained autocracy'. ${ }^{34}$ That restraint was necessary both for the establishment of political legitimacy and because of human nature (in Dio's view, influenced by Thucydides) always leading to a desire to seek mastery over others. Throughout the fragments of the first thirty-five books, Dio issues numerous gnomic statements

30 See de Blois 1998-1999:276, with further references. Dio 12.27, 75.2.5 bears him out here. Cf. Miller 1964:109.

31 Kemezis 2014:113 calls it 'our first fully-surviving example [in Dio] of how public decision-making and discourse works under dynasteia, and it is not an edifying sight'.

32 Dio 37.20, for Pompey's relinquishment of power.

33 Millar 1964:118. This assertion has been much chewed over in the fifty years since.

34 Such a view was also hinted at by Plutarch, eg. Comp. Vit Thes. et Rom. 2. 
on the legitimacy of violence. ${ }^{35}$ For example, we see Dio justifying the desires of many to seek mastery over others in the three following excerpts:

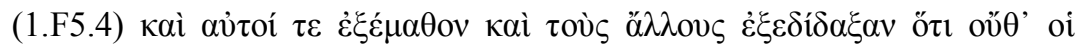

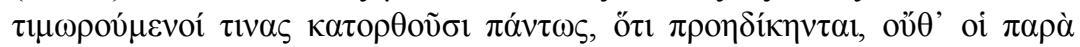

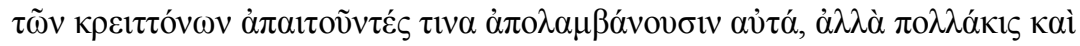

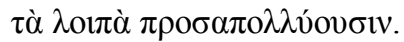

They themselves learned well and taught others the lesson that those who seek to avenge their wrongs are not invariably successful merely because they have first suffered injury, and that those who make demands on stronger men do not necessarily get what they demand, but often lose even what they had before (trans. Cary).

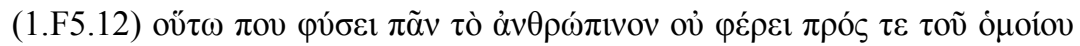

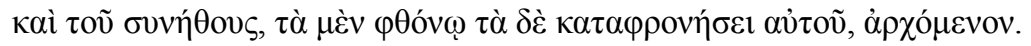

So, no doubt, it is ordered by Nature that whatever is human shall not submit to be ruled by that which is like it and familiar to it, partly through jealousy, partly through contempt of it' (trans. Cary, $c f$. F6.3).

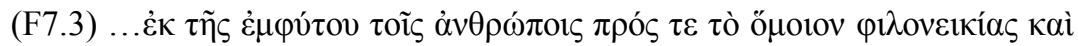

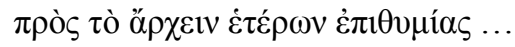

... the inherent disposition of men to quarrel with their equals and to desire to rule others (trans. Cary).

But more than musing about predispositions to rule, Dio suggests that moderation in rule and control is the ideal ...

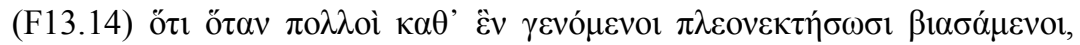

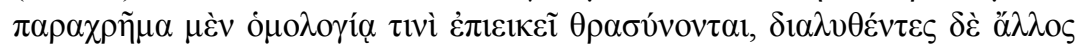

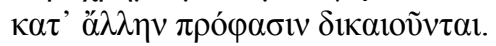

Whenever a large number of men band together and seek their own advantage by violence, they have for the time being some equitable agreement and display boldness, but later they become divided and are punished on various pretexts (trans. Cary).

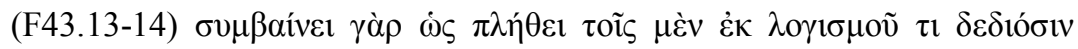

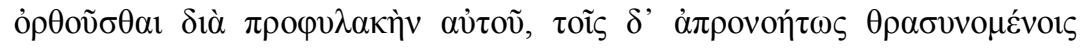

35 Moreover, the pithy nature of these statements, sometimes appearing in isolated fragments, led to their survival. 


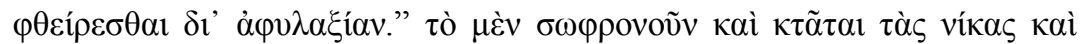

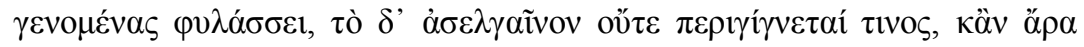

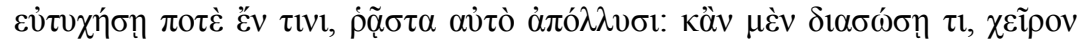

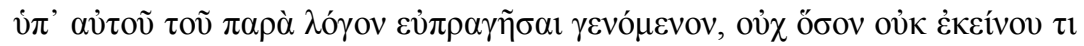

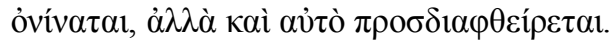

For it usually happens that those who are in dread of something as a result of calculation are successful because of their precaution against it, whereas those who are bold through lack of foresight are ruined because of their unguarded state. Moderation both obtains victories and preserves them after they are won, whereas license can prevail against nothing, and if it ever should be fortunate in any matter, very easily destroys it (trans. Cary).

But while such moderation might be the ideal, reality tends to follow power. Pragmatically, the goal is not to subvert the natural tendency for rule, but to influence it so that the best leaders come into power.

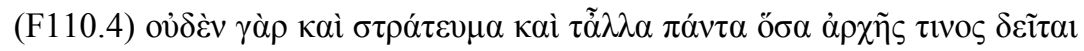

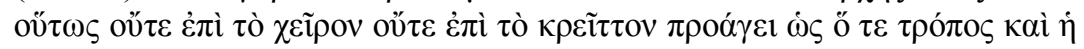

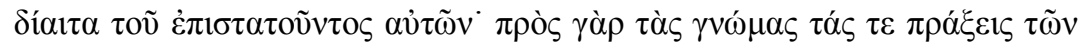

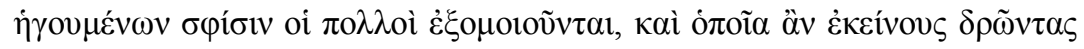

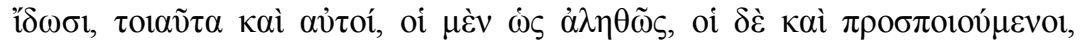
$\pi \rho \alpha ́ \tau \tau o v \sigma \mathrm{v}$.

For nothing leads on an army, or anything else requiring some control, to better or worse like the character and habits of the person presiding over it. The majority naturally imitate the opinions and deeds of their leaders, and do whatever they see them doing, some from real inclination and others as a mere pretence (trans. Cary).

Many other gnomic statements of the sort exist..$^{36}$ A pattern emerges of Dio's philosophy. Humans naturally seek to gain power and to dominate others, pragmatic behaviour is superior to moral behaviour, and power restrains the weak from acting authentically (i.e. those who do not have power lack it because they have failed to get it, not because they do not want it). Despite the negativity imbedded in Dio's description of human nature, the practicable solution is not to stop such violence but rather to control it, so that it is moderated and not excessive (as seen in F13.14 and F43.14 above). Dio has a problem with his fellow historians, namely that the mos maiorum, the very customs that theoretically imposed restraint upon the Romans, were instead alternately causing chaos by

36 See, for example, F12, F24, 8F36f. 
preventing competent leadership in the first place and by failing to impose brakes upon leaders in charge (or doing so on false pretences). Examples of this in Dio can be found at F24 (on the exile of Camillus) and F65 (on Licinius Crassus). ${ }^{37}$

Dio regards such civil conflict as natural - though not truly desirable and predictable. ${ }^{38}$ Arguably, the solution to such civil conflict lay in external conflict, keeping contenders too busy to fight each other. But a brief study here of Dio's presentations of Marius and Sulla, of Pompey and Caesar, and of Antony, Octavian, and Sextus Pompey should put that aside, if for no other reason than the prominence of Dio's comparison of the civil war of 193-197 CE with that of Marius and Sulla (Dio 76.7-8). ${ }^{39}$ That Dio regarded the Mediterranean world of three centuries prior to be comparable is clearly seen also by his assessment of Dalmatia and Pannonia at 49.36 - Dio's own experience is taken as evidence for Octavian's experience. ${ }^{40}$

Cliff Ando correctly argued that Dio does not truly take the emperors to task for their methods of acquiring power as much as what they do with it once they have. ${ }^{41}$ Instead, Dio regards the pragmatic steps they take in establishing their legitimacy to be crucial and pays keen attention to them. Contemporary imperial rule has led Dio to focus upon the pragmatics of imperial succession, and to record methods of accession to power. ${ }^{42}$ Dio does not, however, view this vein of succession as against the mos maiorum, but in keeping with the general philosophy seen in the earlier books. Even in discussing the famous mercy of Caesar, Dio makes a point to observe that he did not grant favours for nothing. ${ }^{43}$ This 'model of imperial legitimacy as based on conventional conduct' is what Dio describes not as something ideal but as something real. ${ }^{44}$ For Dio, imperial succession is not a violation of the mos maiorum, but a normal extension of it. So, while Dio's

37 See also Madsen (2019:472-475) for Dio's view that the earlier days of the Republic did not lack the corruption of the Late Republic.

38 See Madsen 2019:471: 'Although Dio was a firm critic of the ravages of civil war, it is nevertheless important to note that he believed in its transformative effects'.

39 For comparison, see the description of Sulla at Dio 30-35.109.

40 For discussion of this passage of Dio in particular, see Barnes 1984:247-248.

41 Ando 2016:516.

42 As observed by Kelly 2007, e.g. 163-164 the emperor's legitimacy could be harmed by excessive violence just as Pompey's suffered in 52 BCE (see Dio 40.53, 54.7, 60.17 for variously-handled riots).

43 Dio 43.39.5. Dio's Caesar is frequently pragmatic, and Dio excuses certain decisions on the grounds of necessity, such as Caesar's reluctant truce with the Britons (39.51).

44 Quote from Ando 2016:516. Where Ando makes his arguments in comparing the Severans to the ideas laid out in book 53, mine are rooted in comparisons with the powerful figures preceding Augustus in the Late Republic. I remain grateful to Andrew Scott in pointing this article out to me. 
historian counterparts might suggest that a return to the mos maiorum would solve the problems of the Roman Empire, Dio implies that this sort of backward-looking revision would simply recreate the problems.

Much like the famous theory of the 'tragedy of the commons', where what benefits the individual does not benefit society, it only makes sense to Dio that those who can choose to seize and consolidate power should seize and consolidate power, even though to Dio this is ultimately problematic for the senatorial class and for the state as a whole. We see this musing at 5.18, where he suggests the best leaders in war are not the best in peace, and vice versa. It may be worth thinking about this as Dio's 'Tragedy of Power' — in order to effectively gain the rule of the state (and, incidentally, to stay alive as well) it is necessary to take actions that reduce the effectiveness of ruling the state once one actually possesses it.

\section{The noble bandit and the 'tragedy of power'}

This model of 'tragedy of power' served as more than idle navel-gazing, as we can see in Dio's representation of 'noble bandits', men who serve to poke holes in the idea that the best men are in charge. Because of the model Dio has shown for imperial accession, the empire selects for the men who are the best at getting power, not necessarily at using it effectively. So in most cases, the men who are the emperors are not the men who would be best at being emperor. ${ }^{45}$ By showing Roman leaders to be upstaged by far less powerful rivals, rebels, and minor kings, Dio points out some accompanying flaws in what has become the de facto method of attaining power in Rome.

It should be noted here that the nobility retained a certain role in establishing legitimacy, though it had not nearly so much power as even it had had in the late republic. Dio's reading of much second-century literature can likely be taken for granted. We might expect Dio, a la Polybius, to be trying to offer advice to future statesmen, or to explain the intricacies of the Roman state to newlyenfranchised Greeks. Neither seems particularly likely, but Dio does seem to perceive Roman problems with Greek eyes ${ }^{46}$ This is more likely to be due to his readings of authors like Polybius and Diodorus Siculus than representative of early third-century politics.

For our purposes, the 'noble bandit' may be seen as the figure who acts in defiance of the law but consistent with his own moral code. Following from this

45 It remains likely that Dio approved more of the 'Adoptive' Emperors for apparently sidestepping the seizure of power, but this system is not in play for the Late Republic or the third century CE.

46 See de Blois 1984:361-363 for the impact of the new citizen Greeks in the early third century. 
argument, the bandit is primarily defined as an illegitimate figure. This does not necessarily clash with his inner nobility at all. The illicit acts are not necessarily immoral. Indeed, the figures are typically represented to have moral potential, although this development is not realized in the end. But in one form or another, these figures have potential and fail to have legitimate authority.

Dio employs the topos of the noble bandit with the relatively obscure Lusitanian leader Viriathus, who rallies Spain against Roman aggression. Key to the development of the noble bandit figure is the intertwining of physical and mental ability along with the tendency to engage in irregular actions:

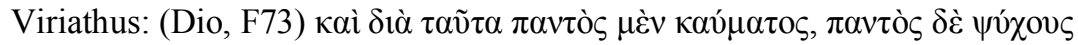

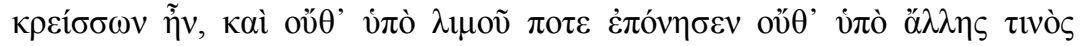

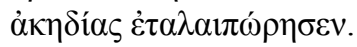

Because of this life, he [Viriathus] was superior to any heat or cold and he never suffered from hunger nor afflicted by any other lack.

Accordingly, Dio's Viriathus looks much like similar leaders in Sallust and Plutarch. ${ }^{47}$ Viriathus may be a tough and hardy foe, but so are Jugurtha, Catiline, and Sertorius:

Jugurtha: (Sall. Iug. 6) pollens viribus, decora facie, sed multo maxume ingenio validus, non se luxu neque inertiae corrumpendum dedit

... strong, handsome, but most of all, intelligent, did not give himself to be corrupted by luxury and laziness ...

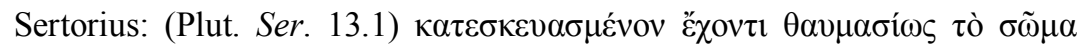

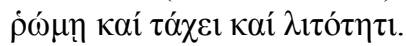

... having a body amazingly equipped with strength, speed, and hardiness.

Catiline: (Sall. Cat. 5.1,3) fuit magna vi et animi et corporis...corpus patiens inediae, algoris, vigiliae supra quam quoiquam credibile est.

[Catiline] had great power both of mind and of body ... He had a body capable of enduring hunger, cold, sleeplessness, more than can be believed by anyone.

47 For the importance of being able to deal with hardship, see Plutarch's comparison of Timoleon and Aemilius, (Comp. Vit. Tim. et Aem. 2.10) where this ability to endure is spelled out as a virtue (and not merely the ability of barbarians). 
These 'noble bandits' also prove themselves to be competent, if often unorthodox, military leaders. ${ }^{48}$ The contemporary Roman counterparts to a figure like Viriathus do not come off well in Dio. For instance, the cruel Caepio was almost murdered by his own men. ${ }^{49}$ Whether by Dio's own interests or those of his excerptors, we are presented with a collection of incompetent and/or wicked Roman leaders, often presented with a virtuous foil.

Dio relies upon his models to construct portraits of the figures in his history. Felix Bulla, while a savage bandit, is also portrayed with redeeming features and a wilful defiance of a hypocritical Roman order. In this way, Bulla appears as a form of the 'noble bandit'. ${ }^{50}$

At this period, one Bulla, an Italian, got together a robber band of about six hundred men, and for two years continued to plunder Italy under the very noses of the emperors and of a multitude of soldiers. [...] Later, he assumed the dress of a magistrate, ascended the tribunal, and having summoned the centurion, caused part of his head to be shaved, and then said: 'Carry this message to your masters: "Feed your slaves, so that they may not turn to brigandage". Bulla had with him, in fact, a very large number of imperial freedmen, some of whom had been poorly paid, while others had received absolutely no pay at all. Severus, informed of these various occurrences, was angry at the thought that though he was winning the wars in Britain through others, yet he himself had proved no match for a robber in Italy; and finally he sent a tribune from his body-guard with many horsemen, after threatening him with dire punishment if he should fail to bring back the robber alive. So this tribune, having learned that the brigand was intimate with another man's wife, persuaded her through her husband to assist them on promise of immunity. As a result, the robber was arrested while asleep in a cave. Papinian, the prefect, asked him, 'Why did you become a robber?' And he replied: 'Why are you a prefect?' Later, after due proclamation, he

48 For a fuller study of the character portraits discussed briefly here (including also Spartacus and some mention of Pompey, but without Felix Bulla), see Beek 2015:258263. Grünewald 2004 remains the standard treatment of Hobsbawm's theory of the noble bandit applied to the Roman world.This sort of portrait also appears for competent Roman enemies like Mithridates and Hannibal, and even allies such as Massinissa of Numidia.

49 Dio F78.

50 See above. See also Shaw 1984:44-46, Van Dam 1977:121f. See Grünewald 2004:124, 133-135, for a push against the noble bandit characterization in favour of 'imperial challenger'. 
was given to wild beasts, and his band was broken up — to such an extent did the strength of the whole six hundred lie in him (trans. Cary). ${ }^{51}$

It is striking to see that Severus is explicitly stated here to be embarrassed by Bulla's success. ${ }^{52}$ The lack of references to Bulla in other sources (notably Dio's contemporary Herodian, though he also appears absent from the $H A$ ) has led some to infer that Bulla was a realistic, but ultimately fictitious character. By this argument, Bulla served as a personification of the all-too-common bandit problem in the Roman Empire, but a problem that is overtly and intentionally acting in opposition to the empire rather than an apparent symptom of the empire's flaws. ${ }^{53}$

This use of Bulla (and that of the peculiar episode of Claudius at 75.2.4) show evidence that Severus was a military leader thinking in terms of military solutions, but also offers a suggestion that some problems might have domestic solutions - those which Severus was ill-equipped to render. Looking back to the books on the Republic, Dio's praise of Pompey's solution of settling the pirates and mild scorn for Caesar dealing only with those bandits that had a political benefit to him suggest that Bulla's line about feeding the slaves to prevent brigandage was entirely within Dio's own views on the matter. ${ }^{54}$

Dio's portrayal at first imagines contemporary Roman leaders relying upon the mos maiorum (suitably interpreted) as a guide to action. This was, after all, still standard practice in Rome. Dio rejects this practice, however, perceiving it as wilfully repeating historical mistakes. Dio tacitly advocates change by not showing

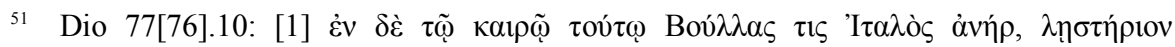

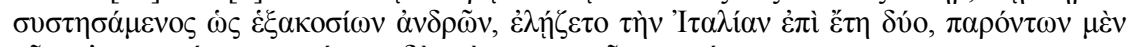

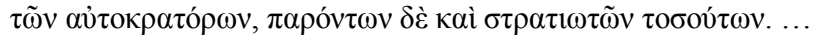

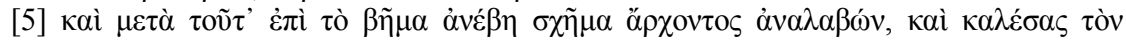

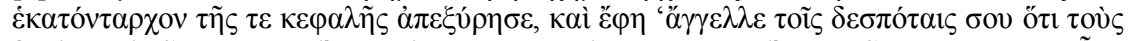

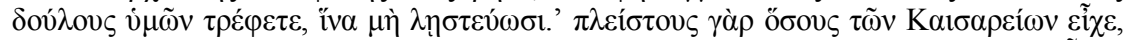

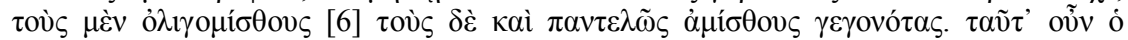

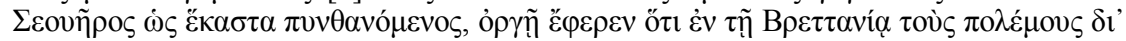

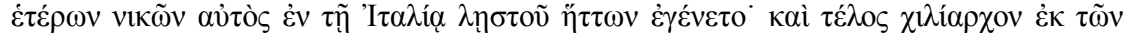

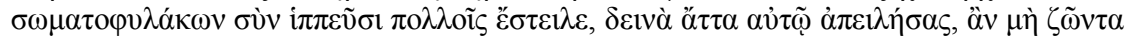

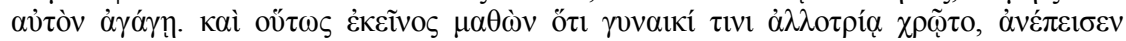

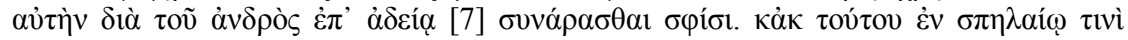

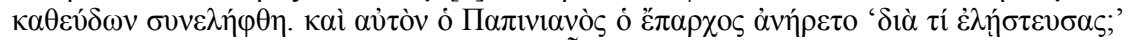

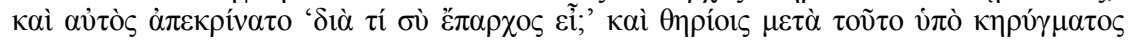

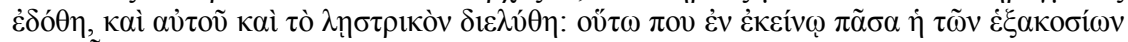
i $\sigma \chi \grave{u} \varsigma \tilde{\eta} v$.

52 According to Birley 1972:242-243, 249, Bulla's success weighed heavily upon Severus.

53 See also Gleason 2011:57-59 on this point.

54 See Coudry 2016 on Pompey here. 
the same adherence to past practice as seen in other Roman historians, nor does he ameliorate the flaws of past Roman heroes.

I also interpret the depiction of mutinies in such a vein. Mutiny is never to be tolerated. ${ }^{55}$ In this, Dio finds himself in good literary company, including both historians like Polybius and anecdotal writers like Valerius Maximus, Plutarch and Polyaenus. What does not escape Dio, however, is that the great leaders of the past, including both Aurelius and Augustus, as well as Julius Caesar, knew that pragmatic negotiation with their soldiers was necessary. ${ }^{56}$ While other authors, (like Polyaenus, writing under the rule of Marcus Aurelius and Lucius Verus), would claim that Julius Caesar would never let a mutineer go unpunished, Dio shows him as willing to negotiate. ${ }^{57}$

At this point, we should reconsider some of the most-famous lines of descriptions of the Severans, particularly the deathbed advice of Severus. ${ }^{58}$ Much ink has already been spilled on interpreting his famous advice to love each other, pay the soldiers, and scorn everyone else. Similarly, Caracalla's call to adjudicate soldiers' minor issues belies the evidence that such a call relies upon the soldiers' willingness to accept his decisions. ${ }^{59}$ Caesar's willingness to execute soldiers who disagree with him, marked by Dio, reflects an important precedent for the empire. ${ }^{60}$

Secondly, when we consider Dio's account of the middle republic (for which we rely heavily on the epitome of Zonaras), we see such a plethora of bad behaviour that we might consider the possibility that Zonaras selected for such examples as most interesting. But more so than in a Livy or a Polyaenus, we see

55 For my purposes here, the words I am examining are: in Latin, forms of the word seditio, and in Greek, participles of the verb $\sigma \tau \alpha \sigma i \alpha ́ \zeta \omega$.

56 See Beek 2020 (forthcoming) for some aspects of this argument at greater length.

57 The sources on Caesar dealing with unrest generally agree that Caesar was very generous up to a point and quite strict thereafter. The main difference is in where that limiting point actually lies. Dio 42.52-55 (presumably the same episode Polyaenus discusses) shows how Caesar discharged some seditious elements with land grants, kept others close, and stationed others in the thick of the fighting. Dio 41.35.5 has Caesar rig the drawing of lots to execute the outspoken. In 43.14, Caesar merely discharges the men. Suet. Iul. 69-70 may be of interest for comparison. Cf. Kemezis 2016 on Caesar's dealing with the Vesontio mutiny. Caesar's own work is not to be trusted on moments he found embarrassing, and he routinely omits such events from his accounts. See Van Stekelenburg 1976:46-47 on this tendency. Here, Dio's apparent sympathy to pragmatic solutions with unruly soldiers resembles Polybius (i.e. his description of the older and younger Scipios) more than most sources on the Republic. See Beek 2020 (forthcoming) on Caesar's portrayal in Polyaenus and Frontinus.

58 Dio 77[76].15.2. Herodian's discussion (2.4) on Pertinax might also be of interest.

59 79[78].1.3 contains a peculiar example, discussed by Scott 2018:30-31.

${ }^{60}$ Some of these are noted above in note 57, i.e. 41.35.5 and 42.55. Harrington 1977:162, also remarks on this tendency. See also Hurlet 2016 for Pompey. 
Romans behaving badly. Moreover, this is of import because it is the middle republic, particularly the end of the third century $\mathrm{BCE}$, that is often taken as the best example of the Roman state. ${ }^{61}$ A description of the bad behaviour of these Roman leaders is often followed by an explanation for how they justified and legitimised it, a literary practice easily recognized in both the early books on the republic and in the late books on the contemporary empire.

Thirdly, the employment of foreigners in the army is a particularly fraught issue for historians. Dio notes times of success and times of peril and has a particular dislike of foreigners in the Praetorian Guard. ${ }^{62}$ This situation creates a very different dynamic in Dio's work: unlike for most of his history, in this case, Dio is a highly-biased eyewitness. Dio considers the emperors to keep shifting the source of their legitimacy to maintain control. As much as Dio dislikes the emperors seeking to establish legitimacy from military supporters rather than senatorial supporters, he is still more suspicious of the emperors claiming legitimacy from 'foreign' military supporters. Likewise, Dio remains suspicious of the influence of freedmen. ${ }^{63}$ The army is prone to banditry, and needs an emperor to keep it in line.

\section{Dio and the Severans}

Dio's Roman history was probably written during the reign of Severus Alexander, and Dio has either gained the freedom to speak more freely about Severus or changed his views on him over the previous decade. Regardless, the Roman history is less positive than earlier writings on Septimius Severus. ${ }^{64}$ As Jussi Rantala argued, this shift may well be due to the abandonment of an initially mild reign in favour of a Sulla-style autocracy after the civil war with Albinus. ${ }^{65}$ Like Sulla (and

${ }^{61}$ Polybius and Sallust both pin 216 BCE (the refusal of the Romans to surrender after Cannae) as the pinnacle of the Roman state and character. Imperial-era writers would of course hearken back to Augustus instead, and indeed Dio spends great effort in describing the late Republic, but also in describing the Augustan state in books 52-53 ... but Dio nevertheless buys into the Polybian / Sallustian model of decline from 216 BCE

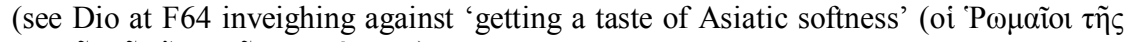

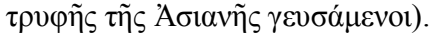

62 See Dio 75[74].2, for remarks on the Praetorian Guard. See Southern \& Dixon 1996:8 for a suggestion that the dislike was a personal bias from his own political career. Dio's recommendations at 52.19f. also suggest ideas along these lines, while 50.2-3 and 57.6 suggest Dio's general dislike of Gauls, whether in the army or elsewhere.

63 See de Blois 1984:366, with further references.

${ }^{64}$ See Barnes 1984 on the composition of Dio's History, cf. Wheeler 1993:18-19, inter alia. See Kemezis 2014 for an analysis of the influence of the official Severan line on Dio's history.

${ }_{65}$ See Rantala 2016:165-166. 
Bulla), Severus acts because he can, and effectively gains authority through impunity. Similarly, Dio (44.1-6) expresses disapproval of Caesar's seizing and using of power, but disapproves the overthrow by the 'Liberators' more, as it would lead to total disorder. We naturally assume disapproval of tyranny, though that may be presumptuous. ${ }^{66}$ While Dio might express the superiority of the senate in a number of places, he is not one to advocate a senatorial overthrow of the emperor.

Regarding Dio's ideas of legitimacy, Caracalla leaps out as a monarch to study, despite the lack of civil war. Dio describes Caracalla as fickle and arbitrary, but perhaps not quite as wholly negatively as generally believed (as Davenport also argues). ${ }^{67}$ Certainly, Caracalla liked spending time with common soldiers, but so also had Pompey and Caesar. Telling is Dio's conclusion at 78[77].11.5: '[He] made many mistakes because of the obstinacy with which he clung to his own opinions; for he wished not only to know everything but to be the only one to know anything, and he desired not only to have all power but to be the only one to have power' (trans. Cary). Therefore, Dio is certainly critical, but does Dio question the legitimacy of Caracalla's state or only the emperor himself? Here the popular acclaim of Pompey in book 36 may be worth reflecting upon. Dio similarly disapproves of the Pompeian method of using popular support to legitimize his largely-unprecedented actions to eliminate illegitimate threats (i.e. by fighting pirates) and corrupt ones (i.e. by co-opting the prolonged campaigns by Metellus and Lucullus). This disapproval is a neat parallel to his disapproval of Caracalla's concessions to the soldiers and wide-scale grants of citizenship to the populace as means of legitimising his consolidation of authority at the partial expense of the aristocratic order. Dio disapproves of Caracalla's seeking legitimacy from the populace and the army, but cannot deny its effectiveness. In other words, Dio effectively explains that this is how Caracalla made his otherwise illegitimate actions legitimate, despite his scorn for the actions themselves. This may also explain his apparent disinterest in the salacious details in other sources - they do not contribute to Dio's explanation of how emperors hold and use power. ${ }^{68}$

The sense of legitimacy as conferred through justified actions rather than through what we might call objectively-appropriate actions again bring Bulla to mind. In equating bandit actions to imperial actions, the objective standard is cast

${ }^{66}$ For example, the tyranny noted by Millar 1961:12, referring to the fragments of book 40 , poses an interesting parallel if we do not presume Dio's disapproval.

${ }^{67}$ See Davenport 2012, passim for Dio's description of Caracalla and the Senate, and 809-810 in particular for the illegitimacy of Caracalla's favoured senators. It should be noted that this is not an argument that Caracalla was viewed positively at the time, but rather that there is good reason to be suspicious of the senatorial tradition given here. 
aside in favour of justification. The prefect's actions were only legitimate because he was the prefect; Caracalla's acts could have been acceptable were he content to accept limits other emperors had. While holding the office of emperor was a de facto claim to legitimacy, Dio clearly outlines the other methods employed by emperors to claim legitimacy for themselves and its lack for their opponents. Personal competence and widespread (alleged) benefits for the populace rise high in imperial claims; we have Caracalla so arguing (78[77].3). Relation and succession weigh in; the pretender Avitus claims adoption by Caracalla, Severus claims adoption by Marcus Aurelius. ${ }^{69}$ The emperor's predecessor is either vilified or deified, and damnatio memoriae becomes popular to an unprecedented degree. ${ }^{70}$ Indeed Dio expresses shock at the way Severus treated the body of Albinus (76[75].7.3-4), but also acknowledges this as effective. Conversely, ambition, while never a negative for the successful claimant, can become excessive ambition. Bribery and rewards appear, successful in some cases, less so in others. ${ }^{71}$ Severus famously denied triumphal honours and sought to portray himself as a defender of the Parthian border, which may resemble the dissembling attempts of Julius Caesar or Augustus to put their civil wars behind them. ${ }^{72}$

Dio seems to expect more and more power devolving to the army. ${ }^{73}$ But unlike other authors, Dio's suggested reforms are not 'return to the old ways'. Rather than advocate such, here he instead proposes the division of Italy and the subdivision of larger provinces (and the armies), as well as training the centuriate to deal with greater number of civil issues that had grown to accompany the military responsibilities. ${ }^{74}$ These are not purely reactionary moves to return to the past, but developments in their own right.

${ }^{69}$ 80[79].2 for Avitus. The retroactive adoption is mentioned as an aside in Dio at 77[76].9.4. See also the claims of Severus to be related to Marcus Aurelius at 76[75].7

70 See Gleason 2011: passim, esp. 37-39 for the impact of damnatio memoriae in this period.

71 Pertinax won over the soldiers (74.1), though he had some trouble finding the money (74.5). Caracalla sought the favour of the army through promises of money and favours (78.3). While donatives on succession had been standard, these appear to have been exceptional.

72 For Severus, see SHA, Sev. 9, 16. For Augustus, see Dio 53.26, 54.12, 27, for the refusal of honours, see Dio 53.7. Kemezis 2014:61-65 also presents a useful discussion in seeing Severus along old Antonine lines, and see also Kemezis 2014:66-69 for his use of building programs.

73 This is well noted by modern scholars. See de Blois 1998-1999:276, Scott 2018:45.

74 See Dio 52.19-28. To what degree we should take Dio as in agreement with his literary Agrippa is a good question, but Dio raising the option is significant in itself. For Italy, see 52.22; for the provinces in general, see his mild approval of dividing provinces into larger numbers at 53.12-14, 59.20.7; for centurions, though it should be obvious that Dio also thinks this would largely be solved by having educated Greeks in these roles, see 


\section{Back to the mos maiorum}

Dio's leaders of Rome are generally harsh, especially towards the Senate, starting

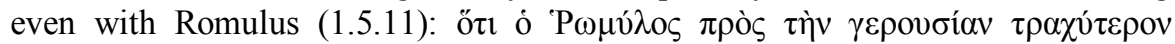

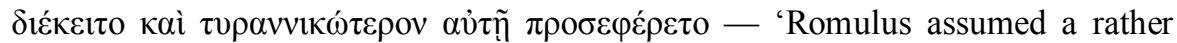
harsh attitude toward the senate and behaved toward it much like a tyrant' (trans. Cary). Dio presents the methods of successful legitimizing moves. Thus we are

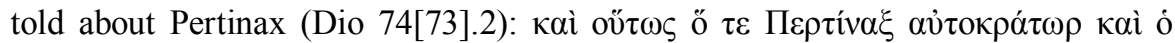
Kó $\mu \mu о \delta о \varsigma \pi 0 \lambda \varepsilon ́ \mu 1 о \varsigma \alpha \dot{\alpha} \pi \varepsilon \delta \varepsilon i ́ \chi \theta \eta$ - 'In this way Pertinax was declared emperor and Commodus a public enemy' (trans. Cary), but the accession of Julianus is marked

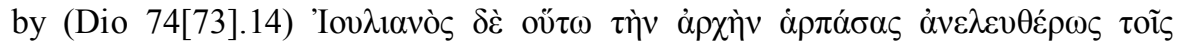

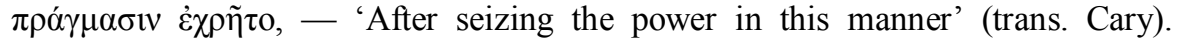
In these two passages, both characters took some similar moves to consolidate their power and boost their legitimacy, but the latter was largely unsuccessful. A key difference may be here the seeking of approval from the Senate by Pertinax and from the Praetorian Guard by Julianus. Likewise, Avitus and Macrinus sought to disparage each other and buy the loyalty of soldiers (80[79].1-2). Yet, Dio's recording of this rhetoric is much the same as seen in the late republic. Failure to achieve public consent of their legitimacy did not mean that they had not tried to achieve legitimacy in a typical fashion. ${ }^{75}$ To Dio's eyes, this is not a situation resolvable by a return to the mos maiorum. Instead, this is what the mos maiorum really was all along.

Briefly, Polybius and his theory of the anacyclosis seem apropos here, as Dio's ideas about monarchy and democracy (most prominently in book 52) seem to be something of a response to the theories of government put forth in book six of Polybius, in Cicero's De re publica, or in Aristotle's Politics (i.e. 3.7-11). ${ }^{76}$ Dio's own view of government cannot match that of Polybius or Aristotle, but it seems

Dio 80.7 for his opinion on centurions rising above their station). See also the analysis of de Blois 1984:369-370, 377.

75 Kemezis 2014, passim but esp. at 4-8, makes a similar point here, though his argument is not framed in terms of legitimacy but in terms of consent and consensus.

76 Scholarship on impact of the anacyclosis of Polybius is exhaustive. Here I may suggest the relatively recent contributions of Erskine and Seager in Gibson and Harrison 2013:231-254. In any case, I think the likelihood of Dio having read Polybius is rather high, despite no mention of this in most discussions of Greek authors' impact on Dio. (cf. Aalders 1986:292-293). Millar's (1964:6-7) discussion of Polybius only lays out trends of Greek historiography, not noting whether Dio follows Polybius as well as Thucydides. Kemezis 2014:22f. discusses their roles as cultural commentators. Notably, Foulon 2016 lays out some evidence for Dio having read Polybius, though he concludes in the negative, as there is no certain proof of the matter. Foulon focuses more on the potential for use of Polybian evidence, but does touch upon the impact of Polybian theory (173-174). 
likely that he was responding to the ideas therein in some way, suggesting a different type of cycle. Dio has no confidence that a reliance on democratic institutions would last long at all. ${ }^{77}$ In studying imperial legitimacy and illegitimacy, he does seem to observe a pattern of changes in who the emperor appeals to for the establishment of legitimacy and the deriding of contenders. Notably, he presents Sulla, Pompey, and Caesar in turn appealing to a progressively more numerous (if generally less powerful) base. Similarly, this appeal to a gradually broader support base seems to also reflect his depiction of the JulioClaudians, the Antonines, and the Severans, who consistently respond to senatorial disapproval with appeals to the soldiers or the general populace. Dio's concept of Tyche also seems not far from that of Polybius. ${ }^{78}$ As Dio would only have used Polybius directly for parts of the Roman history that are now quite fragmentary, it is difficult to argue for direct influence of Polybius on the content. That is not a necessity for an argument about his theory, however.

Dio, like Polybius, sees his historic exempla as guides for future statesmen, though a greater proportion of his examples are negative ones. Certainly, the idea that one might be successful in Rome by emulating the great men of the past was popular during the empire, as can be seen in Tacitus, Plutarch, and Suetonius. This is, of course the very basis of the idea of the mos maiorum. But Dio's use of examples of challenges to imperial authority serve not to suggest a continuation of the customs of the Romans of old, but to suggest that the successful leaders of Rome are those who can tell the difference between customs to keep and customs to break. This is naturally a subjective view, but it is one that paints different good leaders of Rome, like Marcus Aurelius and Augustus not as keepers of tradition, but breakers of it. At the same time, it shows pragmatically that the more villainous emperors are often acting quite effectively when compared to their predecessors, not only emperors and leaders earlier in the empire, but more importantly, in the civil wars of the late republic.

A few words of conclusion: Dio's Roman history cares deeply about the politics of legitimacy. By studying the books on the republic, we find a concern to establish legitimate control over violence, which plays out in controlling the movement and actions of soldiers in foreign wars, grand displays to assert legitimate holding of power and authority in the civil wars, and appeals to the past as precedent in the form of the mos maiorum. Moreover, during the empire, competent men are kept out of power and the idea that the emperors are not shown

77 See Madsen 2016, for some evidence. Dio's clearest statement about democratic and autocratic rule is found at 44.2. One of the characteristics of barbarians is sometimes that they are democratic (e.g. the Britons at 77.12).

78 For some views on Dio's use of tyche, see Aalders 1986:293-294. 
to be the most competent of men is put on display by their comparison to obstacles such as Felix Bulla. The work also displays the emperors as keen historians of their imperial predecessors, albeit historians who privilege the study of retention of power over use of said power. Ultimately, Dio delivers an explanation for why incompetent imperial rule is and will continue to be standard, and the system will continue to deliver inferior emperors so long as the precedent-based mos maiorum holds strong.

\section{BIBLIOGRAPHY}

Aalders, G J D 1986. Cassius Dio and the Greek world. Mnemosyne 39.3-4:282304.

Ando, C 2012. Imperial Rome AD 193-284: The critical century. Edinburgh: Edinburgh University Press.

2016. Cassius Dio on imperial legitimacy, from the Antonines to the Severans. In Fromentin, et al. 2016, 567-580.

Barnes, T D 1984. The composition of Cassius Dio's Roman history. Phoenix 38.3: 240-255.

Beard, M 2007. The Roman triumph. Cambridge, MA: Harvard University Press.

Beek, A L 2015. Freelance warfare and illegitimacy: The historians' portrayal of bandits, pirates, mercenaries and politicians. PhD. Diss, University of Minnesota.

2016. The pirate connection: Roman politics, servile wars, and the East. TAPA 146.1:101-118.

2019. Campaigning against pirate mercenaries: A very Roman strategy? In Evans, R \& de Marre, M (eds.), Pillage, piracy, plunder: Appropriation and the ancient world, 97-114. AClass Supplement 10. New York: Routledge. 2020 (forthcoming). Mercenaries and moral concerns. In Chlup, J, \& Whately, C (eds.), Greek and Roman military manuals: Genre, theory, influence. New York: Routledge.

Bell, S 2008. Introduction: Role models in the Roman world. In Memoirs of the American Academy in Rome. Supplementary volumes, Vol. 7, Role models in the Roman World. Identity and Assimilation, 1-39. Ann Arbor, University of Michigan Press.

Birley, A 1972. Septimius Severus: The African emperor. Garden City: Doubleday. Carsana, C 2016. La teoria delle forme di governo: Il punto di vista di Cassio Dione sui poteri di Cesare. In Fromentin, et al. 2016, 545-558.

Cary E \& Foster, H B (trans.) 1914-1927. Dio Cassius, Roman history, 9 vols. Loeb Classical Library. Cambridge, MA: Harvard University Press. 


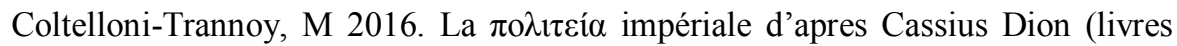
52-59). In Fromentin, et al. 2016, 559-566.

Coudry, M 2016. Cassius Dio on Pompey's extraordinary commands. In Lange \& Madsen 2016, 33-50.

De Blois, L 1984. The third century crisis and the Greek elite in the Roman empire. Historia 33.3:358-377.

De Blois, L 1998-1999. The perception of emperor and empire in Cassius Dio's Roman history. AncSoc 29:267-281.

De Souza, P 1999. Piracy in the Greco-Roman world. Cambridge: Cambridge University Press.

Davenport, C 2017. The sexual habits of Caracalla: Rumour, gossip, and historiography. Histos 11:75-100.

Davenport, C 2012. Cassius Dio and Caracalla. CQ 62.2:796-815.

Devillers, O 2016. Cassius Dion et les sources prétacitéennes. In Fromentin, et al. 2016, 233-242.

Drogula, F 2019. Cato the Younger: Life and death at the end of the Roman Republic. Oxford: Oxford University Press.

Erskine, A 2013. How to rule the world: Polybius book 6 reconsidered. In Gibson \& Harrison 2013, 231-246.

Foulon, É 2016. Pólybe source de Cassius Dion? Bilan d'une aporie. In Fromentin, et al. 2016, 159-178.

Fromentin, V, Bertrand, E, et al. (eds.), 2016. Cassius Dion: Nouvelle lectures. Scripta Antiqua 94. Bordeaux: Ausonius Editions.

Gabrielsen, V 2007. The naval aristocracy of Hellenistic Rhodes. Aarhus: Aarhus University Press.

Gaughan, J E 2010. Murder was not a crime: Homicide and power in the Roman republic. Austin: University of Texas Press.

Gibson, B \& Harrison, T (eds.), 2013. Polybius and his world: Essays in memory of $F W$ Walbank. Oxford: Oxford University Press.

Gleason M 2011. Identity theft: Doubles and masquerades in Cassius Dio's contemporary history. ClAnt 30.1:33-86.

Grünewald T 1999. Räuber, Rebellen, Rivallen, Rächer. Stuttgart: Franz Steiner Verlag.

Grünewald, T 2004. Bandits in the Roman empire: Myth and reality. London: Routledge.

Harrington, D 1977. Cassius Dio as a military historian. AClass 20:159-165.

Havener, W A 2014. Ritual against the rule: The representation of civil war victory in the late Republican triumph. In Lange \& Vervaet 2014, 165-179.

Hurlet, F 2016. De Pompée à Auguste: Les mutations de l'imperium militiae. 1. Les réalités institutionelles. In Fromentin, et al. 2016, 581-594. 
Kelly, B 2013. Policing and security. In The Cambridge Companion to Ancient Rome, 410-424. Cambridge: Cambridge University Press.

Kelly, B 2007. Riot control and imperial ideology in the Roman empire. Phoenix 61.1-2:150-176.

Kemezis, A M 2014. Greek narratives of the Roman empire under the Severans. Cambridge: Cambridge University Press.

Kemezis, A M 2016. The fall of Elagabalus as literary narrative and political reality. Historia 65.3:348-390.

Kemezis, A M 2016. Dio, Caesar, and the Vesontio mutineers (38.34-47): A rhetoric of lies. In Lange \& Madsen 2016, 238-259.

Lange, C H \& Madsen, J M (eds.), 2016. Cassius Dio: Greek intellectual and Roman politician. Leiden: Brill.

Lange, C H \& Vervaet, F J (eds.), 2014. The Roman Republican triumph: Beyond the spectacle. Analecta Romana Instituti Danici. Supplementum, 45. Rome: Edizioni Quasar.

Lange, C H 2016a. Mock the triumph: Cassius Dio, triumph, and triumph-like celebrations. In Lange and Madsen 2016, 92-114. 2016b. Triumphs in the age of civil war. London: Bloomsbury. 2019. Cassius Dio on violence, stasis, and civil war: The early years. In Burden-Strevens, C \& Lindholmer, M O (eds.), Cassius Dio's forgotten history of early Rome. The Roman history, books 1-21, 165-189. Leiden: Brill.

(forthcoming 2020). Cassius Dio on Perusia: A study in human nature during civil war. In Madsen, J M \& Lange, C H (eds.), Cassius Dio the historian: Methods and approaches. Leiden: Brill.

Libourel, J M 1974. An unusual annalistic source used by Dio Cassius. AJP 95: 383-393.

Mabee, B 2009. Pirates, privateers and the political economy of private violence. Global Change, Peace and Security 21:139-152.

Madsen, J M 2019. In the shadows of civil war: Cassius Dio and his Roman history in Lange, C H \& Vervaet, F J (eds.), The historiography of late Republican civil war, 467-501. Leiden: Brill.

McKechnie, P 1981. Cassius Dio's speech of Agrippa: A realistic alternative to imperial government? $G \& R$ 28.2:150-155.

Millar, F 1961. Some speeches in Cassius Dio. $M H$ 18.1:11-22.

Millar, F 1964. A study of Cassius Dio. Oxford: Oxford University Press.

Minyard, J D 1985. Lucretius and the late Republic: An essay in Roman intellectual history. Leiden: Brill.

Moscovich, M J 2004. Cassius Dio's palace sources for the reign of Septimius Severus. Historia 53.3:356-368. 
Rantala, J 2016. Dio the dissident: The portrait of Severus in the Roman history. In Lange \& Madsen 2016, 159-176.

Reinhold, M 1986. In praise of Cassius Dio. AC 55:213-222.

Östenberg, I 2014. Triumph and spectacle: Victory celebrations in the late Republican civil wars. In Lange \& Vervaet 2014:181-193.

Scott, A G 2012. Dio and Herodian on the assassination of Caracalla. $C W 106$ : $15-28$.

2015. Cassius Dio, Caracalla, and the senate. Klio 97:157-175. 2018. A historical commentary on Cassius Dio's Roman history: Emperors and usurpers. (Vol 11.2) Oxford: Oxford University Press.

Schulz, V 2016. Historiography and panegyric: The deconstruction of imperial representation in Cassius Dio's Roman history. In Lange \& Madsen 2016, 276-296.

Seager, R 2013. Polybius' distortions of the Roman 'constitution': A simpl(istic) explanation. In Gibson \& Harrison 2013, 247-254.

Secord, J 2017. Julius Africanus, Origen, and the politics of intellectual life under the Severans. $C W 110: 211-235$.

Shaw, B 1984. Bandits in the Roman empire. $P \& P$ 105:3-52.

Sørensen, S L 2016. Cassius Dio and the foreigners. In Lange \& Madsen 2016, 76-91.

Southern, P \& K Dixon. 1996. The late Roman army. New Haven: Yale University Press.

Tröster, M 2012. Plutarch and mos maiorum in the Life of Aemilius Paullus. AncSoc 42:219-254.

Urso, G 2016. Cassius Dio's Sulla: Exemplum of cruelty and republican dictator. In Lange \& Madsen 2016, 13-32.

Van Dam, R 1977. Heretics, bandits and bishops: Studies in the religion and society of late Roman Gaul and Spain. PhD. Diss. Cambridge.

Van Stekelenburg, A V 1976. Lucan and Cassius Dio as heirs to Livy: The speech of Julius Caesar at Placentia. AClass 19:43-57.

Westall, R 2016. The sources of Cassius Dio for the Roman civil wars of 49-30 BC. In Lange \& Madsen 2016, 51-75.

Wheeler, E L 1993. Methodological limits and the mirage of Roman strategy: Part I. Journal of Military History 57.1:7-41. 